\title{
Analisis Usaha Pemberian Ekstrak Pegagan (Centella Asiatica) Pada Ayam Broiler
}

\author{
Wahyu Arianda', Aisyah Nurmi ${ }^{2}$, Muharram Fajrin Harahap ${ }^{3}$ \\ ${ }^{1}$ Alumni Fakultas Peternakan Program Studi Peternakan Universitas Muhammadiyah \\ Tapanuli Selatan, e-mail :Wahyuregar50@gmail.com \\ ${ }^{2}$ Dosen Program Studi Peternakan Fakultas Peternakan Universitas Muhammadiyah \\ Tapanuli Selatan, e-mail : aisyah.nurmi@um-tapsel.ac.id \\ ${ }^{3}$ Dosen Program Studi Agroteknologi Fakultas Pertanian Universitas Muhammadiyah \\ Tapanuli Selatan, e-mail : muharram.fajrin@um-tapsel.ac.id
}

\begin{abstract}
ABSTRAK
Pembangunan peternakan merupakan bagian penting pembangunan pertanian karena subsektor paternakan merupakan bagian dari sektor pertanian. Dari subsektor peternakan ayam broiler memberikan konstribusi sangat besar dalam perekonomian Indonesia. Setelah diterpa krisis moneter dan adanya wabah penyakit flu burung, bisnis peternakan menghadapi masalah besar untuk kembali pulih. Krisis moneter hampir membuat lumpuh kegiatan sektor peternakan khususnya ternak ayam broiler. Penelitian ini bertujuan untuk mengetahui analisis usaha dengan pemberian ekstrak pegagan (Centella Asiatica) pada air minum ayam broiler.

Rancangan percobaan yang digunakan adalah RAL (Rancangan Acak Lengkap) non faktorial dengan jumlah perlakuan $(\mathrm{t})=4$, ulangan $(\mathrm{n})=5$ dan setiap ulangan $(\mathrm{n})$ terdiri dari 5 ekor ayam sehingga penelitian ini membutuhkan 100 ayam. Dengan perlakuan yaitu P0 : tanpa pemberian ekstrak pegagan (Centela Asiatica), P1 : pemberian ekstrak pegagan (Centela Asiatica) 100 gram, P2 : pemberian ekstrak pegagan (Centela Asiatica) 200 gram, P3 : pemberian ekstrak pegagan (Centela Asiatica) 300 gram. Dari hasil penelitian ini menunjukkan bahwa pemberian ekstrak pegagan (Centela Asiatica) keuntungan tertinggi terdapat pada (300 gram) pemberian ekstrak pegagan (Centela Asiatica) dan keuntungan terendah terdapat pada (0 gram) tanpa pemberian ekstrak pegagan (Centela Asiatica).
\end{abstract}

Kata kunci : broiler, pegagan, analisis usaha

\section{PENDAHULUAN}

Kesadaran masyarakat akan pentingnya pemenuhan gizi hewani membuat tingginya permintaan kebutuhan daging ayam broiler. Permintaan pasar yang tinggi terhadap daging ayam broiler menjadikan ayam jenis ini banyak dibudidayakan oleh peternak. Ayam broiler merupakan ayam ras pedaging yang mampu tumbuh dengan cepat dengan tujuan dapat dipanen dalam waktu yang relatif singkatyaitu sekitar lima hingga enam minggu (Setiawan, 2009). Pembangunan peternakan merupakan bagian penting pembangunan pertanian karena subsektor paternakan merupakan bagian dari sektor pertanian. Dari subsektor peternakan ayam broiler memberikan konstribusi sangat besar dalam perekonomian Indonesia. Setelah diterpa krisis moneter dan adanya wabah penyakit flu burung, bisnis peternakan menghadapi 
masalah besar untuk kembali pulih. Krisis moneter hampir membuat lumpuh kegiatan sektor peternakan khususnya ternak ayam broiler.

Pegagan kaya akan antioksidan dan dapat membantu menyembuhkan gangguan hati termasuk hepatitis, selain itu pegagan juga dapat mengatasi gangguan campak, demam dan sakit tenggorokan karena memilki kandungan antiradang dan anti-infeksinya yang tinggi. Ekstrak daun pegagan dapat berfungsi sebagai hepatoprotektor karena mampu meningkatkann enzim antioksidan seperti superoksidan dismutase (SOD), katalase, glutation peroxidase dan antioksidan glutathione (GSH). Enzim-enzim tersebut sebagian besar didapatkan pada organ hati. Sebagaimana yang kita ketahui hati mempunyai tugas untuk mendetoksifikasi dan mengikatkan diri dengan zat-zat berbahaya bagi tubuh (Syifaiyah, 2008).

Peningkatan jumlah populasi dan tingkat produksi perlu diimbangi dengan peningkatan ketersediaan pakan. Untuk mendapatkan ayam broiler yang cepat dan produktifitas tinggi diperlikan pakan yang cukup mangandung zat-zat makanan yang dibutuhkan, baik secara kualitas maupun secara kuantitas. Zat-zat makanan tersebut seperti karbohidrat, protein, lemak, mineral, dan vitamin harus tersedia dalam ransum. Ransum merupakan komponen biaya terbesar yaitu $60-80 \%$ dari seluruh biaya produksi pada ternak unggas (Rasyaf, 2003). Menekan biaya produksi sekecil mingkin tanpa mengurangi produksi optimum dapat dilakukan dengan cara memanfaatkan bahan pakan alternatif yang tidak bersaing dengan kebutuhan manusia, mempunyai kandungan gizi, mudah didapat dan harganya murah.

Salah satunya dengan memanfaatkan hasil bumi yang tidak bersaing bagi manusia diantaranya adalah tumbuhan pegagan. Tumbuhan pegagan merupakan tumbuhan yang berkembang di tanah yang lembab, dan tumbuhan pegagan diolah/digiling untuk mangambil ekstrak pegagan.

\section{METODE PENELITIAN}

Ternak yang digunakan adalah ayam broiler umur satu hari DOC (day old chiken) sebanyak 100 ekor tanpa membedakan jenis kelamin (unsexing), sampel diambil dari populasi ayam broiler yang diperoleh dari poultry shop, dilakukan pengacakan dan ditempatkan lima ekor setiap petak dan diberi tanda sesuai perlakuan.

\section{Laba Rugi}

Laba rugi merupakan ukuran yang membedakan antara apa yang perusahaan masukkan untuk membuat laporan dan menjual produk dengan apa yang diterimanya. Untuk memperoleh angka yang pasti mengenai tingkat keuntungan atau kerugian suatu usaha, hal terpenting yang perlu dilakukan adalah pencatatan, baik untuk pos-pos pendapatan. 
Laba Rugi adalah nilai yang diperoleh dari total biaya produksi dikurang total produksi. Laba Rugi $=$ Total Biaya Produksi - Total Produksi

\section{Break Even Point (BEP)}

Breack Even Point (BEP) adalah kondisi dimana suatu usaha dinyatakan tidak untung dan tidak rugi yang di sebut titik impas. BEP dapat dibagi menjadi dua.

\section{Income Over Feed Cost (IOFC)}

Income Over Feed Cost (IOFC) diperoleh dengan cara menghitung selisih pendapatan usaha peternakan dikurangi dengan biaya ransum. Pendapatan merupakan perkalian antara produksi peternakan atau pertambahan bobot badan akibat perlakuan (dalam Kilogram hidup) dengan harga jual, sedangkan biaya ransum adalah biaya yang dikeluarkan untuk menghasilkan pertumbuhan bobot badan ternak.

\section{B/C Ratio (Benefit Cost Ratio)}

B/C Ratio adalah nilai atau manfaat yang diperoleh dari setiap satuan biaya yang dikeluarkan.

$\mathrm{B} / \mathrm{C}$ Ratio $=\frac{\text { total hasil produksi }}{\text { total produksi }}$

\section{Rancangan Penelitian}

Rancangan percobaan yang digunakan adalah RAL (Rancangan Acak Lengkap) non faktorial dengan jumlah perlakuan $(\mathrm{t})=4$, ulangan $(\mathrm{n})=5$ dan setiap ulangan $(\mathrm{n})$ terdiri dari 5 ekor ayam sehingga penelitian ini membutuhkan 100 ayam . Ulangan didapat dari rumus :

$\mathrm{T}(\mathrm{n}-1) \geq 15$

$4(\mathrm{n}-1) \geq 15$

$4 \mathrm{n}-4 \geq 15$

$\mathrm{n}>19 / 4=4,75=5$ ulangan

sehingga didapatkan 4 x $5=20$ kombinasi perlakuan.

\section{Teknik Pengumpulan Data}

Pengambilan data dilakukan dengan mengumpulkan semua harga bahan dan harga alatalat yang digunakan selama penelitian sampai kepada penjualan harga ternak. 


\section{HASIL DAN PEMBAHASAN}

\section{Total Biaya Produksi}

Total biaya produksi pada penelitian ini diperoleh dari penjumlahan semua biaya yang dikeluarkan untuk produksi meliputi : biaya bibit, biaya ransum, biaya obat-obatan, biaya tenaga kerja,biaya ekstrak pegagan (Centela Asiatica), biaya perbaikan dan perlengkapan kandang dan biaya sewa kandang. Rataan total biaya produksi dapat dilihat pada grafik berikut :

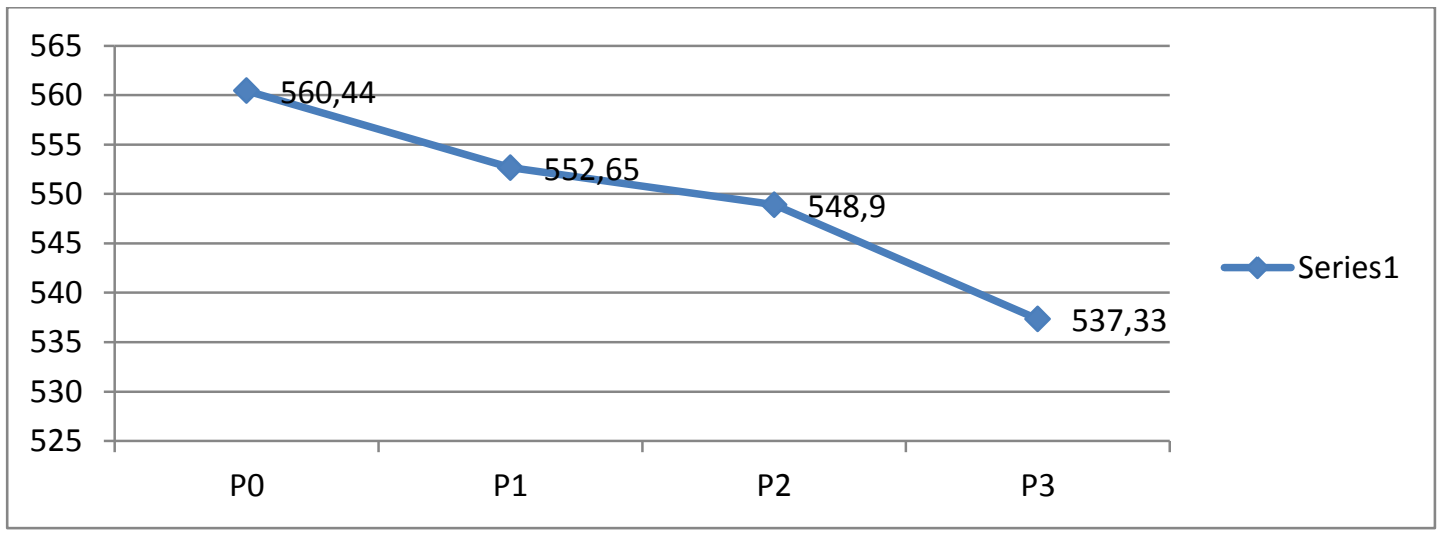

Dari hasil grafik di atas bisa di lihat bahwa hasil total biaya produksi tertinggi pada perlakuan P0 (tanpa pemberian ekstrak pegagan) yaitu sebesar Rp. 560,44,- sedangkan yang terendah terdapat pada perlakuan P3 (dengan pemberian ekstrak pegagan 300 gram/liter air) sebesar Rp. 537,33,-.Hal ini menunjukan bahwa dengan pemberian ekstrak pegagan dapat mengurangi total biaya produksi jika dibandingkan dengan biaya produksi yaitu dengan pemberian ekstrak pegagan.

\section{Total Hasil Produksi}

Total hasil produksi pada hasil penelitian ini diperoleh dari penjumlahan semua biaya yang diperoleh dari hasil produksi yaitu penjualan ayam broiler. Pada penelitian ini total hasil produksi hanya di peroleh dari penjualan penjualan ayam.

\subsubsection{Hasil Penjualan Ayam}

Penjualan ayam diperoleh dari harga jual ayam perkilogram. Harga penjualan ayam yaitu sebesar Rp.25.000 perkilogram. Untuk mengetahui hasil penjualan ayam tiap perlakuan dapat dilihat pada grafik berikut: 


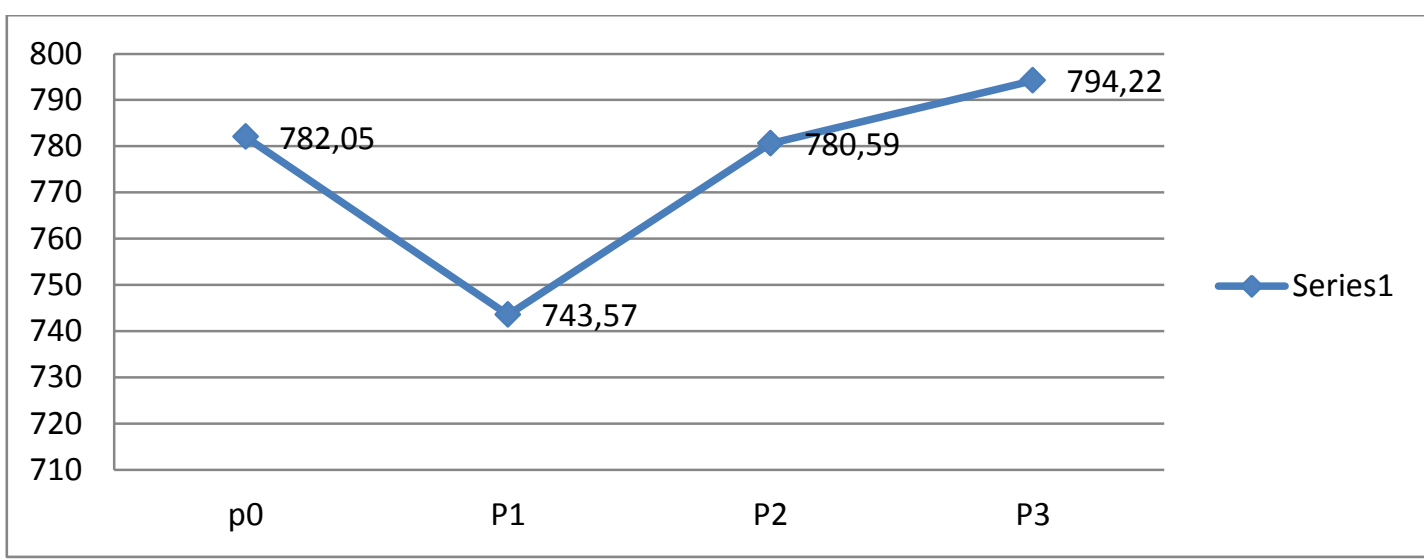

Dari hasil grafik di atas dapat di lihat bahwa hasil penjualan ayam terbesar diperoleh pada perlakuan P3 (dengan pemberian ekstrak pegagan 300 gram/liter air) yaitu sebesar Rp. 794,22,- dan yang terendah penjualan ayam diperoleh pada perlakuan P1 (dengan pemberian ekstrak pegagan 100 gram/liter air) sebesar Rp. 743,57,--

\section{Analisis Laba-Rugi}

Analisis usaha atau laba-rugi dilakukan untuk mengetahui apakah usaha tersebut untung atau rugi dengan cara menghitung selisih antara total hasil produksi dengan total biaya produksi.

Keuntungan $=$ Total hasil produksi-total biaya produksi

Total hasil produksi yaitu total penjualan ternak memiliki nilai yang lebih tinggi dari pada total biaya produksi yaitu biaya bibit, biaya ekstrak pegagan (Centela asiatica), biaya ransum, biaya obat-obatan, biayaupah (tenaga kerja), biaya perlengkapan kandang dan biaya sewa kadang. Untuk mengetahui hasil dari semua penjumlahan mari kita lihat grafik berikut:

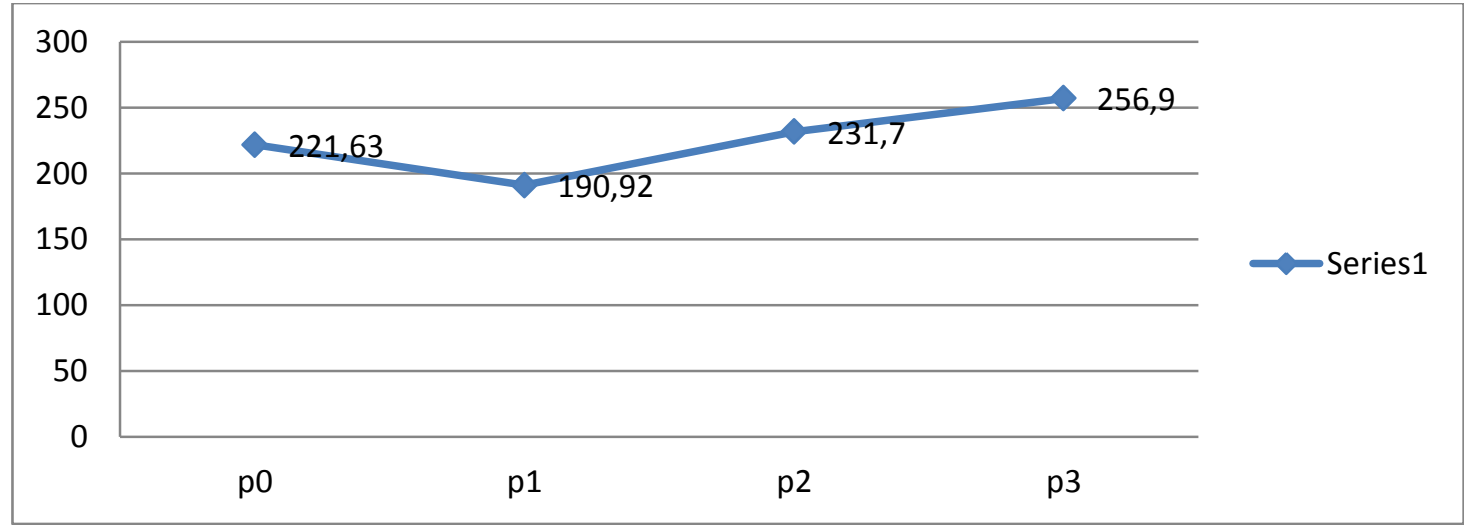

Dari hasil grafik dapat di lihat hasil tertinggi pada perlakuan P3 (dengan pemberian ekstrak pegagan 300 gram/liter air) yaitu sebesar Rp. 256,90,- dan keuntungan terendah pada 
perlakuan P1(dengan pemberian ekstrak pegagan 100 gram/liter air) yaitu sebesar Rp. $190,92,-$.

\section{Break Event Point (BEP)}

Break event point (BEP) yaitu kondisi dimana suatu usaha dinyatakan tidak untung dan tidak rugi dan disebut titik impas. Break event point (BEP) dapat dibagi menjadi dua yaitu: 4.4.1 Break Event Point (BEP) Harga Produksi Pada penelitian ini break event point untuk harga produksi diperoleh dari hasil pembagian total biaya produksi dengan berat hidup ternak dan biaya tersebut dapat dilihat pada grafik berikut:

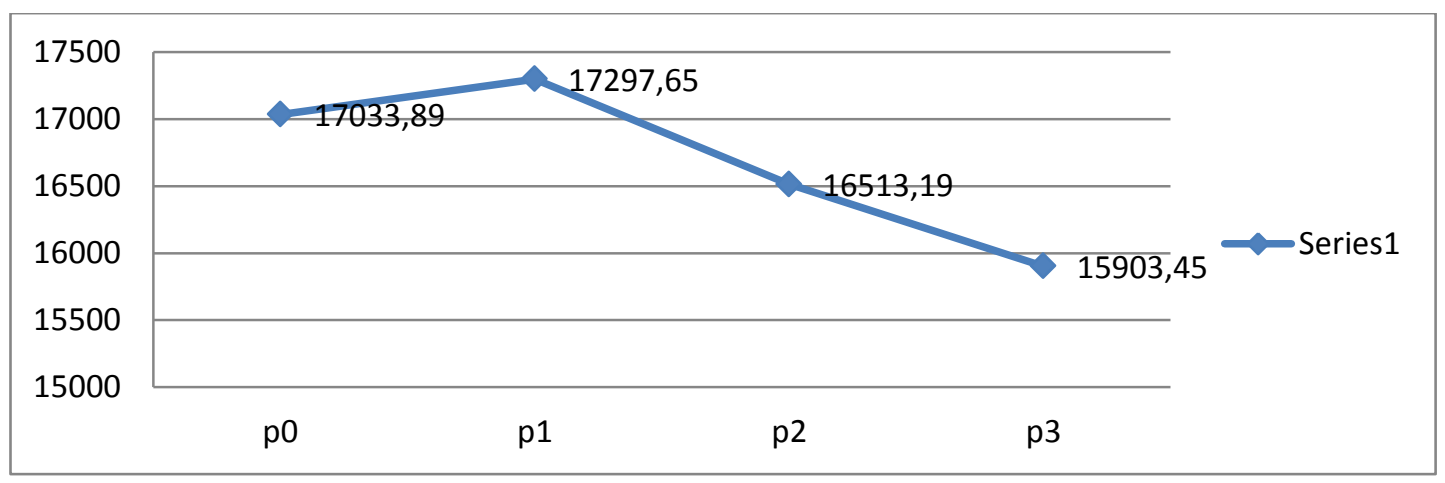

Dari hasil grafik di atas dapat di lihat bahwa hasil dari BEP harga produksi akan tercapai bila harga bobot badan hidup P0 (tanpa pemberian ekstrak pegagan) sebesar Rp. 17033,89,- P1 (dengan pemberian ekstrak pegagan 100 gram/liter air) sebesar Rp. 17297,65,- P2 (dengan pemberian ekstrak pegagan 200 gram/liter air) sebesar Rp. 16513,19,- P3 (dengan pemberian ekstrak pegagan 300 gram/liter air) sebesar Rp. 15903,45,-

\subsubsection{Break Event Point (BEP) Volume Produksi}

Break Event Point untuk volume produksi dimana dapat diperoleh dari pembagian total biaya produksi dengan harga ayam $(\mathrm{Rp} / \mathrm{Kg})$. Berikut dapat dilihat pada grafik berikut:

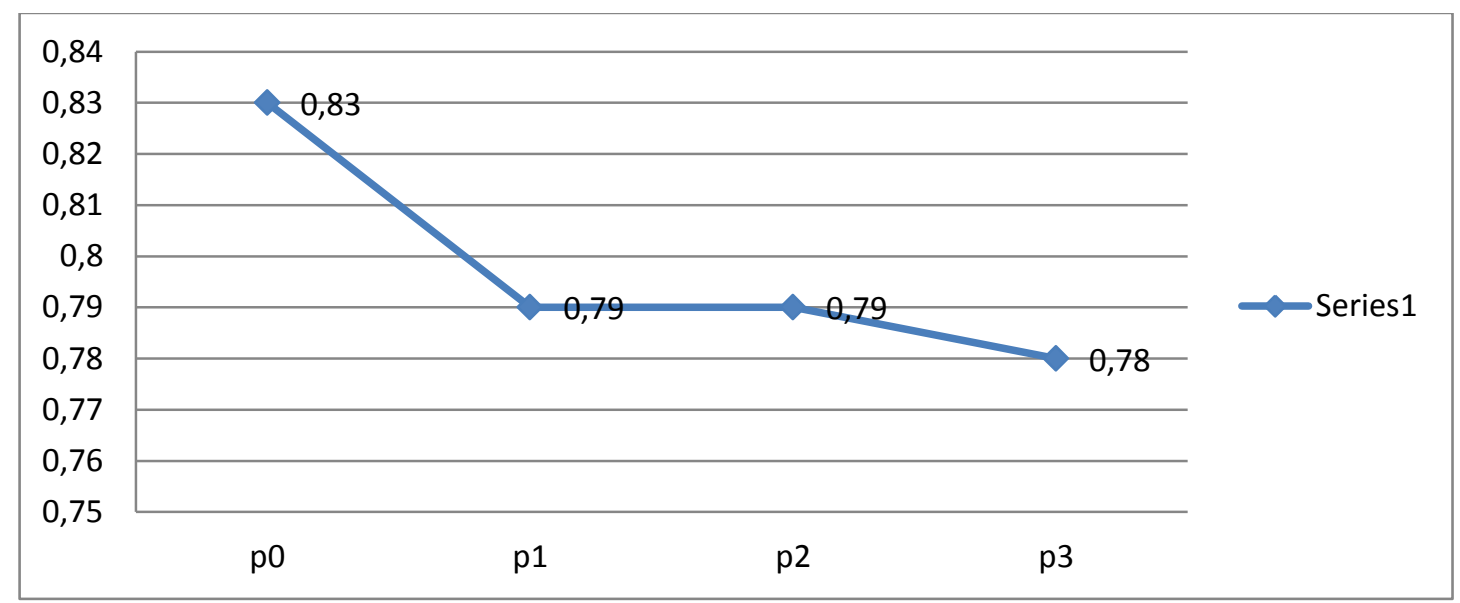


Dari hasil grafik di atas dapat dilihat hasil yang diperoleh bahwa titik modal akan tercapai jika berat ayam yang dihasilkan pada P0 sebesar $0,83 \mathrm{Kg}, \mathrm{P} 1$ sebesar $0,79 \mathrm{Kg}, \mathrm{P} 2$ sebesar 0,79 Kg, dan P3 0,78 Kg. Agar biaya yang telah dikeluarkan dapat kembali.

\section{Income Over Feed Cost (IOFC)}

Income over feed cost (IOFC) adalah selisih dari total pendapatan usaha ternak dengan dikurangi biaya pakan. Income over feed cost (IOFC) ini merupakan barometer untuk melihat besar biaya pakan yang merupakan biaya terbesar dalam usaha pemeliharaan ternak. Biaya tersebut dapat dilihat pada grafik berikut:

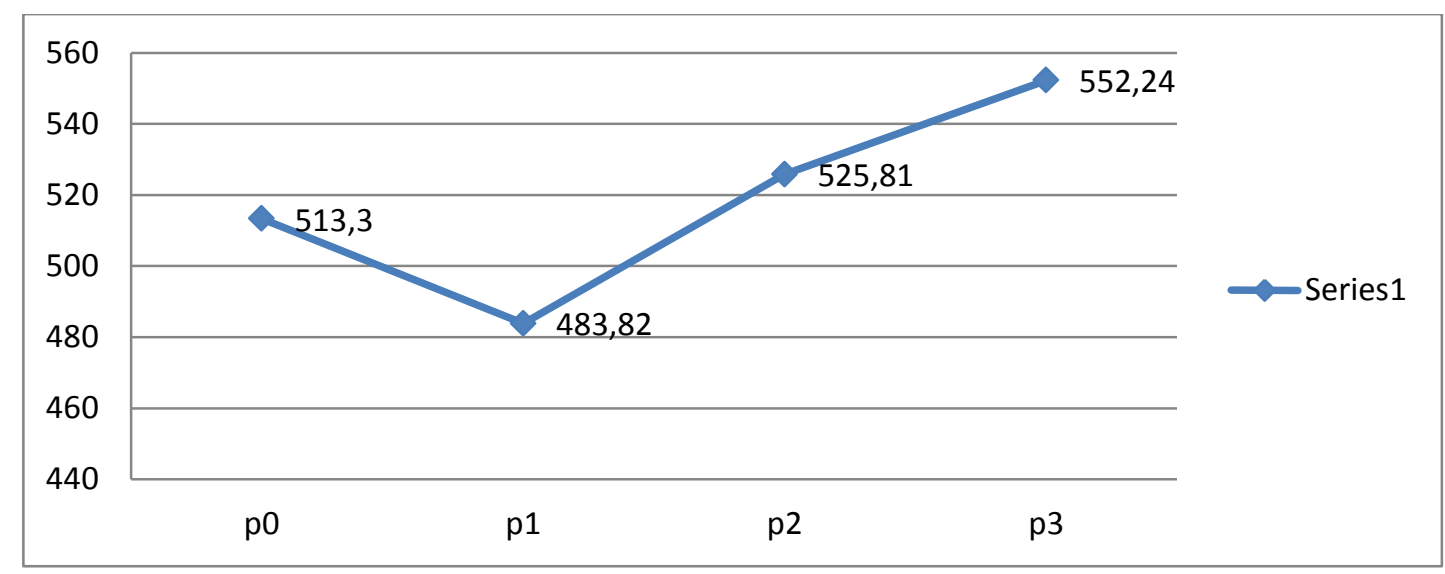

Dari hasil grafik di atas dapat di lihat hasil IOFC terbesar terdapat pada perlakuan P3 sebesar Rp. 552,24,- dan IOFC terkecil terdapat pada perlakuan P1 sebesar Rp. 483,82,-. Hal ini sesuai dengan pernyataan Prawirokusumo (1990) yang menyatakan bahwa Income Over Feed Cost (IOFC) adalah selisih total pendapatan penjualan ayam dengan biaya pakan yang digunakan selama usaha pemeliharaan ternak.

\section{Benefit Cost Ratio (B/C Ratio)}

Analisis B/C Ratio digunakan dalam suatu usaha untuk mengetahui layak atau tidak layak usaha itu dilanjutkan ke periode berikutnya atau sebaliknya usaha tersebut dihentikan karena kurang layak. Berikut dapat dilihat pada grafik berikut:

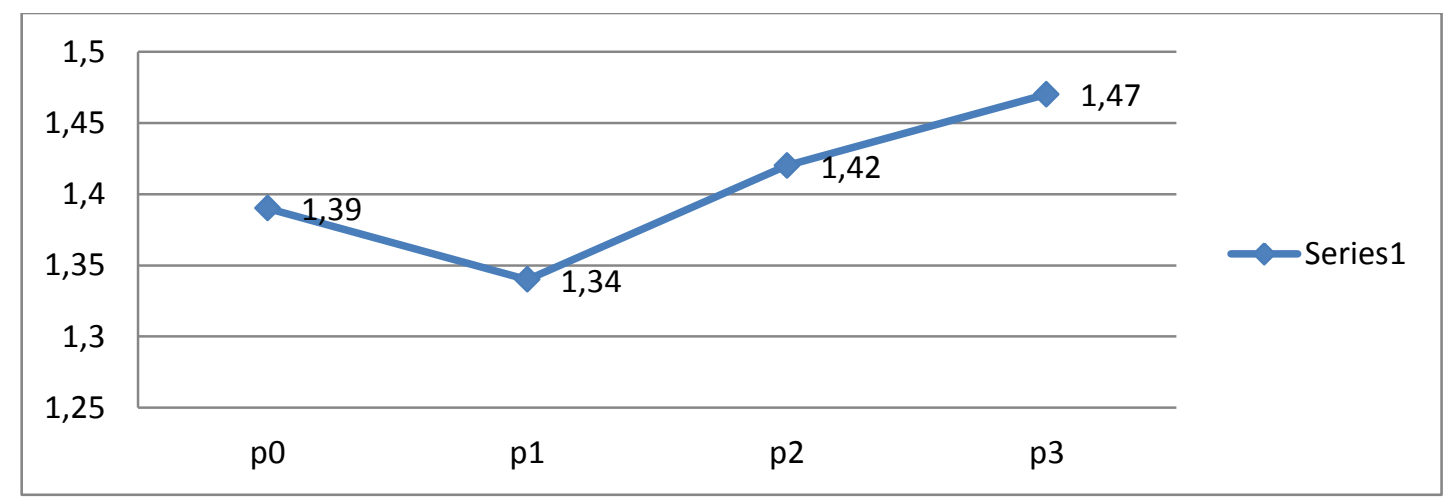


Dari hasil grafik di atas dapat di lihat hasil B/C Ratio yang diproleh menunjukkan bahwa pemberian ekstrak pegagan (Centela asiatica) pada air minum layak untuk dilanjutkan karena rataan dari semua perlakuan memiliki hasil rataan sebesar 1,41 dengan nilai rataan B/C Ratio tertinggi terdapat pada perlakuan P3 (dengan pemberian ekstrak pegagan 300 gram/liter air) yaitu sebesar 1,47 dan nilai B/C Ratio terendah diperoleh pada perlakuan P1 (dengan pemberian ekstrak pegagan 100 gram/liter air) yaitu sebesar 1,34. Hal ini sesuai dengan pernyataan Karo-karo, et all (1995) bahwa suatu usaha dapat dikatakan memberikan keuntungan bila nilai B/C Ratio diatas $1(>1)$.

\section{Rekapitulasi Hasil Penelitian}

Rekapitulasi hasil penelitian pengaruh pemberian ekstrak pegagan (Centela Asiatica) terhadap analisis usaha dapat dilihat pada Tabel berikut.

Tabel 4.17 Tabel Rekapitulasi Hasil Penelitian

\begin{tabular}{lcccc}
\hline \multirow{2}{*}{\multicolumn{1}{c}{ Parameter }} & \multicolumn{4}{c}{ Perlakuan } \\
\cline { 2 - 5 } & P0 & P1 & P2 & P3 \\
\hline Total Biaya Produksi & $560,44^{\text {tn }}$ & $552,65^{\text {tn }}$ & $548,90^{\text {tn }}$ & $537,33^{\text {tn }}$ \\
Total Hasil Produksi & $782,05^{\text {tn }}$ & $743,57^{\text {tn }}$ & $780,59^{\text {tn }}$ & $794,22^{\text {tn }}$ \\
Keuntungan Laba-Rugi & $221,63^{\text {tn }}$ & $190,92^{\text {tn }}$ & $231,70^{\text {tn }}$ & $256,90^{\text {tn }}$ \\
BEP Harga Produksi & $17033,89^{\text {tn }}$ & $17297,65^{\text {tn }}$ & $16513,19^{\text {tn }}$ & $15903,45^{\text {tn }}$ \\
BEP Volume Produksi & $0,83^{\text {tn }}$ & $0,79^{\text {tn }}$ & $0,79^{\text {tn }}$ & $0,78^{\text {tn }}$ \\
IOFC & $513,30^{\text {tn }}$ & $483,82^{\text {tn }}$ & $525,81^{\text {tn }}$ & $552,24^{\text {tn }}$ \\
B/C Ratio & $1,39^{\text {tn }}$ & $1,34^{\text {tn }}$ & $1,42^{\text {tn }}$ & $1,47^{\text {tn }}$ \\
\hline
\end{tabular}

Dan dari data hasil rekapitulasi diatas telah dilakukan analisis keragaman pada tiap parameter yang diamati, dan diketahui bahwa dari hasil keseluruhan memberikan pengaruh yang tidak nyata pada semua parameter. Hal ini berarti pemberian ekstrak pegagan (Centela asiatica) tidak mempengaruhi terhadap total hasil produksi yang pada akhirnya tidak berpengaruh juga pada analisis usaha (parameter). Namun demikian dari penelitian ini, perlakuan yang menunjukkan hasil terbaik terdapat pada perlakuan P3 (dengan pemberian ekstrak pegagan 300 gram/liter air).

\section{KESIMPULAN}

Hasil penelitian ini menunjukkan bahwa pemberian ekstrak pegagan (Centela Asiatica) pada air minum ayam broiler tidak memberikan pengaruh yang nyata pada analisis ekonomi ayam broiler, tetapi kesimpulan dari perlakuan yang telah saya berikan pada air minum ayam broiler layak untuk dilanjutkan pada perktek usaha ayam broiler dengan level yang berbeda di atas dari 300 gram yang saya berikan. 


\section{DAFTAR PUSTAKA}

Abidin, 2002. Meningkatkan Produksitivitas Ayam Ras Pedaging, Agromedia Pustaka.

Budiono, 1990. Ekonomi Mikro, BPFE: Yogjakarta.

Fadillah, 2004. Kunci Sukses Beternak Ayam Broiler di Daerah Tropis, Agromedia Pustaka.

Hansem dan Mowen, 2001. Manajemen Biaya, Salemba Empat: Jakarta.

Hansen dan Mowen, 2004. Ko Manajemen Biaya, Salemba Empat: Jakarta.

Harnanto dan Zulkifli, 2003. Manajemen Biaya, edisi pertama, cetakan pertama, Yogyakarta : UPP AMP YKPN

Januwati, 2002. Klasifikasi Tanaman Pegagan (Centela asiatica) Balai Penelitian Tanaman Obat Dan Aromatika.

Januwati, M. dan M. Yusron. 2005. Budidaya Tanaman Pegagan. Balai penelitian dan Pengembangan Pertanian. Balai Penelitian Tanaman Obat dan Aromatika.

Kabarudin, (2008). Penambahan Pegagan Sebagai Suplemen Dan Penambah Nafsu Makan Selama Pemeliharaan Ayam.

Kadarsan, 1995. Keuangan Pertama dan Pembiayaan Perusahaan Agribisnis, PT. Gramedia Pustaka Utama: Jakarta.

Kasim, Ifdhal, 2002. Hak Sipil dan Politik, Jakarta: ELSAM Wahyu, 1997,

Kasmir dan Jakfar, 2005. Studi Kelayakan Bisnis, Kencana: Jakarta. 